\title{
STUDI KEMAMPUAN THREE POIN SHOOT BOLA BASKET PUTRA PADA CLUB BOLA BASKET KOTA BENGKULU TAHUN 2018/2019
}

\author{
Aad Ryan Malta \\ Universitas Bengkulu email :aadryanmalta@gmail.com \\ Yarmani \\ Universitas Bengkulu \\ Ari Sutisyana \\ Universitas Bengkulu
}

\begin{abstract}
Abstrak
Penelitian ini bertujuan untuk mengetahui kemampuan three poin shoot pada permainan bola basket. Studi kemampuan thre poin shoot pada club bola basket Kota Bengkulu. Metode dalam penelitian ini adalah deskriptif dengan pendekatan kuantitatif, yang berarti penelitian ini hanya meneliti kemampuan atlet bola basket dan tes berupa praktek three poin shoot. Subjek dari penelitian ini adalah atlet bola basket putra pada club kota bengkulu yang etlet nya berjuamlah 65 orang. Pada penelitian ini akan melihat hasil tes dan persentase kemampuan atlet. Pada Studi berdasarkan teknik dapat disimpulkan, pada fase unjuk kerja sebesar 18,46\% dengan katagori nilai Kurang, dan 67,69\% dengan katagori nilai Cukup, dan 13,84\% dengan katagori nilai Baik dan berdasarkan biomekanika dari ketiga club tersebut dengan presentase sebagai berikut, pada fase posisi awal sebelum melakukan three poin shoot dengan baik dan benar sebesar $100 \%$, dan pada fase cara memegang bola dengan baik dan benar sebesar $100 \%$, dan pada fase posisi siku dengan baik dan benar $69,23 \%$, dan pada fase pergelangan tangan dan tubuh harus segaris dengan ring dengan baik dan benar sebesar 76,92\%. Kemampuan yang paling baik dilakukan oleh ketiga club tersebut ialah posisi awal sebelum melakukan three poin dan cara memegang bola dan keterampilan yang paling buruk ialah posisi siku.
\end{abstract}

Kata Kunci : Kemampuan Three Poin Shoot, dan Biomekanika, Club Bola Basket Kota Bengkulu

\begin{abstract}
This study aims to determine the ability of three shoot points in basketball games. Study of thre's ability to shoot at the Bengkulu City basketball club. The method in this study is descriptive with a quantitative approach, which means that this study only examines the ability of basketball athletes and tests in the form of three shoot shoot practices. The subjects of this study were male basketball athletes in the city club of Bengkulu, with an etlet of 65 people. in this study will see the test results and the percentage of athletes' abilities. In the study based on techniques it can be concluded, in the performance phase of $18.46 \%$ with the category of Less value, and $67.69 \%$ with the category of Sufficient value, and $13.84 \%$ with the category of value Good and based on the biomechanics of the three clubs with percentage as the following, in the initial position phase before carrying out three points shoot well and correctly by $100 \%$, and at the phase of how to hold the ball properly and correctly by $100 \%$, and at the elbow position phase properly and correctly $69.23 \%$, and at the
\end{abstract}


phase wrist and body must be in line with the ring properly and correctly at $76.92 \%$. The best ability performed by the three clubs is the initial position before doing three points and how to hold the ball and the worst skill is the position of the elbow.

Keywords : Ability of Three Point Shoot, and Biomechanics, Bengkulu City Basket Ball Club

\section{PENDAHULUAN}

Olahraga merupakan salah satu aktivitas jasmani dan rohani yang di lakukan oleh manusia. Olahraga telah menjadi rutinitas sehari-hari bagi masyarakat untuk menjaga kekebalan tubuh dan melindungi diri agar tidak mudah terserang penyakit. Dalam dunia pendidikan, olahraga Bola Basket juga di ajarkan setiap sekolah, baik di dalam mata pelajaran, maupun dalam kegiatan ektrakurikuler. Dalam menunjang prestasi maka setiap club biasanya tersedia sekelompok remaja yang tergabung dalam tim basket club yang mewakili club untuk bertanding dalam kejuaraan-kejuaraan bola basket yang di adakan club lain, maupun pemerintah. Kegiatan ini juga sangat didukung oleh pemerintah dalam setiap daerah. Hanya saja, setiap daerah memiliki fasilitas yang berbeda. Kejuaraan bola basket club di Kota Bengkulu saat ini telah berkebang sangat pesat, hal ini di lihat dari banyaknya club yang mengadakan acara kejuaraan bola basket antar club se-kota bengkulu, dan barubaru ini pengurus PERBASI (Persatuan Bola Basket Seluruh Indonesia) kota Bengkulu baru saja mengadakan LIGA basket se-kota Bengkulu. Pencapain prestasi dalam bidang olahraga itu di tentukan dan di pengaruhi oleh banyak faktor yaitu faktor dari dalam maupun dari diri sendiri (internal) dan dari luar (ekternal). Dalam permainan bola basket, ada yang dinamakan tembakan tiga angka atau sering disebut Three poin shoot. Maka shooting tiga angka ini sangat berguna untuk mendapatkan poin supaya tim bisa unggul jauh dari tim lain. namun pada pertandingan antar club sekota
Bengkulu sangat sulit untuk mendapatkan tembakan tiga angka, karena kurangnya latihan intensif yang hanya terkhusus untuk shooting Three poin shoot.

Berdasarkan wawancara awal dengan seorang pelatih bola basket club di Kota Bengkulu bahwa kemampuan dasar shootThree poin hanya dapat di lakukan oleh beberapa pemain hal ini dapat di lihat dari pembelajaran shooting, dalam permainan bola basket kurang di perkenalkan dan kurang di pelajari oleh seluruh pemain ataupun atlet secara mendalam. Dari pernyataan di atas, maka peneliti tertarik untuk melakukan penelitian dengan judul Analisis KemampuanThree poin shoot pada club basket putra Kota Bengkulu.

Menurut Steohen P. Robins (2005: 46) dalam Samuel Surantha (2017: 10) mengatakan bahwa kemampuan (ability) adalah kapasitas individu untuk melaksanakan berbagai tugas dalam pekerjaan tertentu, (kemampuan, ketangkasan, bakat, kesangupan) merupakan tenaga melakukan suatu prubahan. Menurut Singer dalam Santoso (2012: 13) dalam Rige gietra (2017: 8) Kemampuan adalah derajat keberhasilan yang konsisten dalam mencapai suatu tujuan dengan efektif dan efisien ditentukan oleh kecepatan, Kemampuan, bentuk, dan kemampuan menyusuaikan diri. Menurut Abidin dalam santoso (2012: 13) dalam Rige gietra (2017: 9) untuk dapat memiliki Kemampuan gerakan yang baik, maka diperlukan proses belajar, berlatih dalam waktu yang relatif lama.

Menurut Aminudin $(2008 ; 17)$ Bola basket adalah olahraga bola besar berkelompok yang terdiri atas dua tim 
beranggotakan masing-masing lima orang yang saling bertanding mencetak poin dengan memasukan bola kedalam keranjang lawan. Bola basket adalah salah satu olahraga yang paling digemari oleh penduduk amerika serikat dan penduduk di belahan bumi lainnya, antara lain di Amerika Selatan, Eropa Selatan, Lithuania, dan juga Indonesia Menurut Hall wissel (1996: 2) bola basket dimainkan oleh dua tim dengan 5 pemain per tim. Tujuannya adalah mendapatkan nilai (skor) dengan memasukan bola ke keranjang dan mencegah tim lain melakukan hal serupa. Bola dapat diberikan hanya dengan passing (operan) dengan tangan atau dengan mendriblenya bebrapa kali pada lantai tanpa menyentuh dengan dua tangan secara bersamaan. Teknik dasar mencakup footwork(gerakan kaki), shooting (menembak), passing (mengoper) dan menangkap, drible, rebound, bergerak dengan bola, bergerak tanpa bola, bertahan. Menurut Muhajir dalam Agus Purnama (2007: 22) Permainan bola basket merupakan suatu cabang olahraga di mana hampir semua unsur gerakan tubuh manusia di pergunakan

Menurut Adnan Fardi (1999; 35) menembak meruakan cara atau usaha memasukan bola kedalam keranjang atau ring lawan. Untuk bisa menguasai teknik menembak pemain harus memiliki tingkat ketepatan yang tinggi. Three poin shoot adalah teknik tembakan tiga angka. Tembakan ini biasanya hanya dilakukan di luar garis Three poin. Dalam melakukan tembakan Three poin shoot dibutuhkan teknik yang halus dan berirama serta mekanisme tubuh yang baik. Menurut Madri M. (20019: 74) mengatakan bahwa Three pon shoot adalah salah satu senjata untuk memenangkan pertandingan, juga membalikan keadaan saat tim mengalami kekalahan
Menurut kosasi (2008: 52) dalam

Rige gietra (2017: 27) mengatakan bahwaThree poin shoot adalah salah satu senjata untuk memenangkan pertandingan juga membalikan keadaan atau keungulan disaat tim kita mengalami kekalahan Dalam Della Junea Afandi danGigih Siantoro (2017) Tembakan Tiga Poin. Tiga angka merupakan nilai tertinggi yang dapat di peroleh dalam permainan bolabasket.

\section{METODE}

Sesuai dengan permasalahan serta tujuan penelitian yang sudah di bahas sebelumnya, bahwa penelitian yang di maksud adalah Analisis KemampuanThreePoin ShootBola Basket Putra Pada Club Kota Bengkulu. Ada banyak Club Basket di Kota Bengkulu ini dan peneliti hanya mengambil 3 Club saja. Jenis penelitian ini adalah penelitian lapangan yang bersifat deskriptif analisis yang menggunakan pendekatan kualitatif. Deskriptif hanya mengambarkan situasi yang sedang berlangsung, tanpa penguji hipotesis. Metode yang di lakukan adalah survey yaitu pengumpulan data di lapangan.

Sugiono, (2006: 6) menyatakan bahwa metode survey di gunakan untuk mendapatkan data dari tempat tertentu yang alamiah (bukan buatan), tetapi peneliti melakukan perlakuan dalam pengumpulan data, misalkan dengan mengedarkan tes wawancara, intruksi dan sebagainya berdasarkan penjelasan peneliti akan mengambil data bila dilapangan. Teknik ini menggunakan teknik pengumpulan data berupa katakata tertulis atau lisan, gambar, foto, atau tindakan yang di peroleh dari sumber data, yaitu : orang tulisan dan tempat
a. Pengamatan (observasi)
b. Tes Three Poin Shoot 
Tes three poin shoot ini dilakuakan sebanyak 5 kali percobaan dan setiap melakukan shoot ke dalam ring akan mendapatkan poin 3 angka dan apa bila tidak masuk maka poin nya kosong agar atlet termotivasi untuk mamasukan bola yang ada dan tidak membuang kesempatan yang ada saat melakukan three poin shoot. Dari lembar observasi, peneliti akan mencatat semua kesalahanThree poinshoot yang di lakukan oleh atlet pada club patriots, Poltekes, dan Tunas di Kota Bengkulu. Peneliti akan menghitung kesalahan yang terjadi data yang ada di unjuk kemampuan dan mempersentasikannya.

Untuk mengetahui persentase yang dilakukan maka digunakan rumus statiskika sebagai berikut:

$$
\mathrm{P}=\frac{f}{n} \times 100 \%
$$

Keterangan:

$\mathrm{P}=$ Presentase tingkat Kemampuan

$f=$ Jumlah ceklis dalam lembar observasi $n=$ Jumlah atlet

(Sumber: Arsil 2010 dalam Rige gietra 2017: 38

\section{HASIL DAN PEMBAHASAN}

Tabel 1 Instrumen Penilaian Norma Tes Three Poin Shoot Tunas

\begin{tabular}{c|c|c|c} 
No & $\begin{array}{c}\text { Rentang } \\
\text { Skor }\end{array}$ & $\begin{array}{c}\text { Kriteria } \\
\text { skor }\end{array}$ & $\begin{array}{c}\text { Jumlah } \\
\text { Atlet }\end{array}$ \\
\hline 1 & $0-2$ & $\begin{array}{c}\text { Kurang } \\
\text { Sekali }\end{array}$ & Orang \\
\hline 2 & $3-5$ & Kurang & $\begin{array}{c}14 \\
\text { Orang }\end{array}$ \\
\hline 3 & $6-8$ & Cukup & 1 orang \\
\hline 4 & $9-11$ & Baik & 0 \\
\hline 5 & $12-15$ & $\begin{array}{c}\text { Baik } \\
\text { Sekali }\end{array}$ & 0
\end{tabular}

Berdasarkan hasil penelitian yang saya lakukan dan mendapatkan hasil penelitian dari 5 kali kesempatan melakukan three poin shoot didapatkan hasil sebagai berikut: 50rang atlet dengan persentase $=$ $\frac{5}{20} \times 100 \%=$

$25 \%$ dengan katagori kurang

14Orang atlet dengan persentase $=\frac{14}{20} \times 100 \%=$

$70 \%$ dengan katagori cukup

1 Orang atlet dengan persentase $=\frac{1}{20} \times 100 \%=$

$5 \%$ dengan katagori baik

Tabel 2 Instrumen Penilaian Norma Tes Three Poin Shoot Patriots

\begin{tabular}{c|c|c|c} 
No & $\begin{array}{c}\text { Rentang } \\
\text { Skor }\end{array}$ & $\begin{array}{c}\text { Kriteria } \\
\text { skor }\end{array}$ & $\begin{array}{c}\text { Jumlah } \\
\text { Atlet }\end{array}$ \\
\hline 1 & $0-2$ & $\begin{array}{c}\text { Kurang } \\
\text { Sekali }\end{array}$ & 2 Orang \\
\hline 2 & $3-5$ & Kurang & $\begin{array}{c}13 \\
\text { Orang }\end{array}$ \\
\hline 3 & $6-8$ & Cukup & 5 Orang \\
\hline 4 & $9-11$ & Baik & 0 \\
\hline 5 & $12-15$ & $\begin{array}{c}\text { Baik } \\
\text { Sekali }\end{array}$ & 0
\end{tabular}

Berdasarkan hasil penelitian yang saya lakukan dan mendapatkan hasil penelitian dari 5 kali kesempatan melakukan three poin shoot didapatkan hasil sebagai berikut:

20rang atlet dengan persentase $=$ $\frac{2}{20} \times 100 \%=$

$10 \%$ dengan katagori kurang

130rang atlet dengan persentase $=\frac{13}{20} \times 100 \%=$

$65 \%$ dengan katagori cukup

1 Orang atlet dengan persentase $=\frac{1}{20} \times 100 \%=$

$5 \%$ dengan katagori baik

Tabel 3 Instrumen Penilaian Norma Tes Three Poin Shoot Poltekes

\begin{tabular}{c|c|c|c} 
No & $\begin{array}{c}\text { Rentang } \\
\text { Skor }\end{array}$ & $\begin{array}{c}\text { Kriteria } \\
\text { skor }\end{array}$ & $\begin{array}{c}\text { Jumlah } \\
\text { Atlet }\end{array}$ \\
\hline 1 & $0-2$ & Kurang & 5 Orang
\end{tabular}




\begin{tabular}{c|c|c|c} 
& & Sekali & \\
\hline 2 & $3-5$ & Kurang & $\begin{array}{c}17 \\
\text { Orang }\end{array}$ \\
\hline 3 & $6-8$ & Cukup & 3 orang \\
\hline 4 & $9-11$ & Baik & 0 \\
\hline 5 & $12-15$ & $\begin{array}{c}\text { Baik } \\
\text { Sekali }\end{array}$ & 0
\end{tabular}

Berdasarkan hasil penelitian yang saya lakukan dan mendapatkan hasil penelitian dari 5 kali kesempatan melakukan three poin shoot didapatkan hasil sebagai berikut:

50rang atlet dengan persentase $=$ $\frac{5}{25} \times 100 \%=$

$20 \%$ dengan katagori kurang

170rang atlet dengan persentase $=\frac{17}{25} \times 100 \%=$

$68 \%$ dengan katagori cukup

3 Orang atlet dengan persentase $=\frac{3}{25} \times 100 \%=$

$12 \%$ dengan katagori baik

Berdasarkan hasil penelitian dari 3 club bola basket Kota Bengklulu dan sebanyak 65 atlet dihasilkan sebagai berikut:

$\mathrm{P}=\frac{f}{n} \times 100 \%=\frac{12}{65} \times 100 \%=18,46 \%$ dengan katagori nilai Kurang

$\mathrm{P}=\frac{f}{n} \times 100 \%=\frac{44}{65} \times 100 \%=67,69 \%$ dengan katagori nilai Cukup

$\mathrm{P}=\frac{f}{n} \times 100 \%=\frac{9}{65} \times 100 \%=13,84 \%$ dengan katagori nilai Baik

Setelah mendapatkan data atlet yang telah melakukan three poin shoot yang terdapat dalam lembar observasi, maka di hitung besaran persentase sebagai berikut:

1. Analisi berdasarkan biomekanika

a. Posisi awal sebelum malakukan three poin shoot
$\mathrm{P}=\frac{f}{n} \times 100 \%=\frac{25}{25} \times 100 \%=100 \%$

b. Cara memegang bola

$\mathrm{P}=\frac{f}{n} \times 100 \%=\frac{25}{25} \times 100 \%=$ $100 \%$

c. Posisi Siku

$\mathrm{P}=\frac{f}{n} \times 100 \%=\frac{15}{25} \times 100 \%=$ $60 \%$

d. Pergelangan tanggan dan tubuh segaris dengan ring

$\mathrm{P}=\frac{f}{n} \times 100 \%=\frac{20}{25} \times 100 \%=$ $80 \%$

Setelah mendapatkan data atlet yang telah melakukan three poin shoot yang terdapat dalam lembar observasi, maka di hitung besaran persentase sebagai berikut:

1. Analisi berdasarkan biomekanika

a. Posisi awal sebelum malakukan three poin shoot

$\mathrm{P}=\frac{f}{n} \times 100 \%=\frac{20}{20} \times 100 \%=100 \%$

b. Cara memegang bola

$\mathrm{P}=\frac{f}{n} \times 100 \%=\frac{20}{20} \times 100 \%=100 \%$

c. Posisi Siku

$\mathrm{P}=\frac{f}{n} \times 100 \%=\frac{15}{20} \times 100 \%=75 \%$

d. Pergelangan tanggan dan tubuh segaris dengan ring

$\mathrm{P}=\frac{f}{n} \times 100 \%=\frac{15}{20} \times 100 \%=75 \%$

Setelah mendapatkan data atlet yang telah melakukan three poin shoot yang terdapat dalam lembar observasi, maka di hitung besaran persentase sebagai berikut:

1. Analisi berdasarkan biomekanika

a. Posisi awal sebelum malakukan three poin shoot

$\mathrm{P}=\frac{f}{n} \times 100 \%=\frac{20}{20} \times 100 \%=100 \%$

b. Cara memegang bola

$\mathrm{P}=\frac{f}{n} \times 100 \%=\frac{20}{20} \times 100 \%=100 \%$

c. Posisi Siku

$\mathrm{P}=\frac{f}{n} \times 100 \%=\frac{15}{20} \times 100 \%=75 \%$

d. Pergelangan tanggan dan tubuh segaris dengan ring 


$$
\mathrm{P}=\frac{f}{n} \times 100 \%=\frac{10}{20} \times 100 \%=50 \%
$$

Berdasarkan hasil dari hasil tes kemampuan menembak three poin shoot yang dilakukan terhadap atlet dari ketiga club bola basket yaitu; club Poltekes, Patriots, dan Tunas maka jumlah hasil tes three poin shoot yang mendapat nilai sangat kurang hanya $18,46 \%$ dengan jumlah atlet 12 orang kemudian yang mendapat nilai hanya $67,69 \%$ dengan jumlah atlet 44 orang dan yang mendapatkan nilai baik hanya $13,84 \%$ dengan jumlah atlet 9 orang maka hasil dari keseluruhan hanya 99,99\% dengan jumlagh atlet 65 orang.

Maka hasil dari tes unjuk kerja three poin shoot maka yang mendapat nilai kurang sekali hanya $18,46 \%$, dengan jumlah atlet 12 orang dan yang mendapat nilai kurang hanya $67,69 \%$ dengan jumlah atlet 44 orang, dan yang mendapat nilai cukup hanya $13,84 \%$ dengan jumlah atlet 9 orang. Dari penjalasan hasil penelitian diatas dapat disimpulkan bahwa 65 atlet dari tiga club bola basket kota bengkulu berada pada norma nilai cukup dikarenakan setiap club hanya melaksanakn latihan 1 kali dalam seminggu kemudian apabila hasil dari ketiga club bola basket Kota Bengkulu maka intensitas latihannya harus dilakukan selama 3-5 kali perminggu, sedangkan hari yang lain digunakan untuk istirahat sehingga sehinga sesuai dengan kondisi kemampuann three poin shoot dalam katagori cukup sesuai dengan teori yang ada.

Menurut Djoko Pekik (2000:13) keberhasilan program untuk mencapai kebugaran sangat ditentukan oleh kualitas latihan yang meliputi tujuan latihan, pemilihan model latihan, penggunaan sarana latihan yang lebih penting lagi adalah takaran atau dosis latihan yang dijabarkan dalam konsep FIT (frekuensi, intensity, and time). a. Frekuensi. Banyaknya unit latihan persatuan waktu. Pada program kebugaran jasmani memerlukan latihan 3-5 kali perminggu, sedangkan hari yang lain digunakan untuk istirahat atau recovery. Tidak diperbolehkan latihan beban setiap hari karena tubuh akan mencapai titik jenuh.

b. Intensitas. Kualitas yang menunjukkan berat ringannya latihan tersebut. Besarnya intensitas bergantung pada jenis dan tujuan latihan. Latihan aerobik menggunakan patokan kenaikan detak jantung ( Training Heart Rate $=$ THR). Secara umum intensitas untuk kebugaran adalah $60 \%-90 \%$ denyut jantung maksmal dan secara khusus besarnya intensitas latihan bergantung pada tujuan latihan.

c. Time. Waktu yang diperlukan setiap kali berlatih. Untuk meningkatkan kebugaran paru jantung dan kebugaran berat badan diperlukan waktu berlatih 20-60 menit. Hasil latihan kebugaran terlihat setelah berlatih selama 8 sampai dengan 12 minggu dan akan stabil setelah 20 minggu berlatih.

\section{Simpulan}

Berdasarkan hasil penelitian yang telah di uraikan, dapat di kemukakan bahwa kesimpulan hasil yang diperoleh dari kemampuan three poin shoot pada atlet bola basket Kota Bengkulu ialah sebagai berikut, Terdapat presentase yang cukup dalam melakukan three poin shoot dengan rata-rata presentase sebagai berikut;

Pada Studi berdasarkan teknik dapat disimpulkan, pada fase unjuk kerja sebesar $18,46 \%$ atau 12 atlet dengan katagori nilai Kurang, dan $67,69 \%$ atau 44 atlet dengan katagori nilai Cukup, dan $13,84 \%$ atau 9 atlet dengan katagori nilai 
Baik dan berdasarkan three poin shoot dengan biomekanika dari ketiga club tersebut dengan presentase sebagai berikut, pada fase posisi awal sebelum melakukan three poin shoot dengan baik dan benar sebesar $100 \%$, dan pada fase cara memegang bola dengan baik dan benar sebesar $100 \%$, dan pada fase posisi siku dengan baik dan benar 69,23\%, dan pada fase pergelangan tangan dan tubuh harus segaris dengan ring dengan baik dan benar sebesar 76,92\%. Kemampuan yang paling baik dilakukan oleh ketiga club tersebut ialah posisi awal sebelum melakukan three poin dan cara memegang bola dan keterampilan yang paling buruk ialah posisi siku.

\section{Saran}

Bedasarkan hasil penelitian yang di lakukan, berikut ini penulis menyampaikan beberapa saran yang berkaitan dengan penelitian ini.

1. Atlet hendaknya memahami teknik dasar three poin shoot, dan biomekenika dalam melakukan three poin shoot.

2. Pelatih hendak nya lebih meningkatkan latihan-latihan yang berkaitan dengan three poin shoot sehingga atlet lebih baik dalam melakukan three poin shoot.

3. Perlu adanya latihan khusus untuk three poin shoot karena thre poin shootmerupakan bagian terpenting dalam pertandingan bola basket.

4. Para atlet harus memiliki satu tujuan yang bulat dan keras untuk bisa menguasai kemampuan three poin shoot supaya ilmu yang dimiliki dapat bermanfaat bagi orang lain.

\section{DAFTAR PUSTAKA}

Aminudin. 2008 Aneka Cabang Olahraga, Bandung: $\mathrm{Cv}$ Mutiara Ilmu Bandung
Arikunto, Suharsimi. 2010 Prosedur penelitian suatu pendekatan praktik. Jakarta:Rinike Cipta

Fardi, Adnan. 1999 Bola Basket dasar. Padang: DIP Universitas Negeri Padang

Gietra, Rige 2017. Analisi Keterampilan Shooting Free Trow Pada Siswa Peserta Ekrakurikuler SMPN 1. Kota Bengkulu (skripsi).Bengkulu Universitas Bengkulu

Madri, M.2012. Teknik Dasar Pembelajran Basket. Padang: Sukabina Press.

Olivier, Jon. 2009. Dasar-Dasar Bola Basket. Bandung: Pakar Karya

Suratantha Samuel, 2017, Analisi Kemampuan Teknik Heading Siswa Ektrakurikuler Futsal SMP Negeri 13. Kota Bengkulu

Sugiyono. 2011. Metode Penelitian Kuantitatif Kualitatif dan $R \& D$. Bandung Alfabeta Bandung.

Setiana, Tono, dan Sugiyanto. 2018. "Pengaruh Latihan Terpusat dan Latihan Acak Terhadap Hasil Penguasaan Teknik Dasar Bola Basket". Jurnal Kinestetik, Vol. 2 (1).

Wissel, Hal 1996. Bola Basket, Program Pemahiran, Tkenik, dan Taktik. Jakarta; Rajagrafindo Persada 